\title{
CONSTRAINTS ON POLITICAL AUTONOMY IN DECENTRALIZED SPAIN? ANALYSING THE IMPACT OF TERRITORIAL FINANCING AND GOVERNMENTS' IDEOLOGY ON REGIONAL POLICY-MAKING
}

¿Condicionantes de la autonomía política en la España descentralizada?

Análisis del impacto de la financiación territorial y de la ideología en el policy-making regional

\author{
RAQUEL GALLEGO \\ Universitat Autònoma de Barcelona \\ raquel.gallego@uab.cat \\ NICOLÁS BARBIERI \\ Universitat Autònoma de Barcelona \\ nicolas.barbieri@uab.cat \\ CRISTINA DE GISPERT \\ Universitat de Barcelona \\ crisdegispert@ub.edu \\ SHEILA GONZÁLEZ \\ Universitat Autònoma de Barcelona \\ sheila.gonzalez@uab.cat \\ MAITE VILALTA \\ Universitat de Barcelona \\ mvilalta@ub.edu
}

Cómo citar/Citation

Gallego, R., Barbieri, N., Gispert, C. de, González, S. y Vilalta, M. (2018).

Constraints on political autonomy in decentralized Spain? Analysing the impact of territorial financing and governments' ideology on regional policy-making.

Revista de Estudios Políticos, 180, 131-162. doi: https://doi.org/10.18042/cepc/rep.180.05 


\begin{abstract}
This article analyses the impact of state decentralization on one aspect of territorial diversity, specifically on the policy discretion of regions, as an expression of their political autonomy for self-government. Our interest focuses on the factors that determine the decisions and actions of regional governments in developing their policies. We ask: why do regional governments take different public policy options? Conceding that several factors help explain policy decisions (such as productive structure, government ideology, social capital, political context, budgetary resources), we choose to explore the impact of two of them, by asking: in what way, and to what extent, are policy decisions and actions conditioned by the financing model and by their different ideologies? We present quantitative and qualitative comparative evidence from two contrasting case studies: two regions in decentralized Spain that have developed their own policies of income and spending, and have translated them into differing public management policies and regulatory models for providing health services. These governments are ideologically different and have undergone different degrees of recent ideological changes, but the resources provided to them by the financing model have also been different. We show how resources determine the scope of governments' actions, while ideology determines their direction.
\end{abstract}

\title{
Keywords
}

Decentralization; public policy; ideology; territorial financing system; Spain; health system.

\section{Resumen}

Este artículo analiza el impacto de la descentralización del Estado en un aspecto de la diversidad territorial, concretamente en la discrecionalidad de las políticas públicas regionales, como una expresión de su autonomía política para el autogobierno. Nuestro interés se centra en los factores que determinan las decisiones y acciones de los Gobiernos subcentrales en el desarrollo de sus políticas públicas. Nos preguntamos: ¿por qué los Gobiernos regionales toman diferentes opciones de políticas públicas? Asumiendo que son diversos factores los que ayudan a explicar las decisiones de políticas públicas (tales como la estructura productiva, la ideología del Gobierno, el capital social, el contexto político, los recursos presupuestarios...), escogemos explorar el impacto de dos de ellos, preguntándonos: ¿de qué forma, y en qué medida, sus decisiones de políticas y acciones de políticas públicas han sido condicionadas por el modelo de financiación y por sus diferentes ideologías? Presentamos evidencia comparativa, cualitativa y cuantitativa de dos estudios de caso: dos comunidades autónomas en España que han desarrollado sus propias políticas de ingresos y de gasto, y las han traducido en políticas de gestión pública y modelos regulativos de los servicios de salud distintos. No solo sus Gobiernos han sido ideológicamente distintos y han 
pasado por diferentes grados de cambios ideológicos, sino que también los recursos que se les han asignado a través del modelo de financiación han sido distintos. Mostramos cómo los recursos determinan el alcance de las acciones de los Gobiernos, mientras que su ideología determina su dirección.

\section{Palabras clave}

Descentralización; políticas públicas; ideología; financiación territorial; España; sistema sanitario. 


\section{CONTENTS}

I. INTRODUCTION. II. FISCAL FEDERALISM AND POLICY ANALYSIS: THE THEORY OF REFERENCE. III. THE REGIONAL FINANCING MODEL: SAME BUDGET CONSTRAINTS FOR ANDALUSIA AND CATALONIA?: 1. The availability and source of resources during the period 2001-2011: are differences between Andalusia and Catalonia observed?: 1.1. Regional financing agreements of 2001 and 2009. 1.2. The financing agreement of 2001. 1.3. The financing agreement of 2009. 2. Beyond the resources from the funding model. IV. HEALTH POLICY DECISIONS IN ANDALUSIA AND CATALONIA: THE INFLUENCE OF IDEOLOGY?: 1. Managing the budget: Spending decisions as policy decisions. 2. Changing health public management: Why and how?: 2.1. Catalonia: Formulating the Law of the Catalan Health Institute. 2.2. Andalusia: Expanding the network of Hospital Centres of High Resolution. V. FINANCING MODEL AND IDEOLOGY: HOW DO THEY INFLUENCE REGIONAL POLITICAL AUTONOMY? V. CONCLUSIONS. BIBLIOGRAPHY. ANNEX.

\section{INTRODUCTION}

The effects of decentralization in States is a major issue in comparative literature from various disciplines, mainly due to the diversity of social, economic and political impacts that this process may have across the territory. Hence, most of these studies focus on the potential inequalities that may occur between regions (McEwen and Moreno, 2005; Gallego, 2016; Gallego, 2014; Guillén and León, 2011; Rodríguez-Pose, 2004). However, in this article, we start from the basis that the States are, in fact, geographically diverse in their political, economic and social conditions and that this holds true whether they are unitary or decentralized. Therefore, we understand that decentralization will have different impacts on different territories because these are, to begin with, different. That is, even supposing that the powers and decentralized resources are equivalent in the different territories of a State, their governments will deploy actions in different political, social and economic contexts, so it is expected that the content and outcome of their performances will also be different.

In this regard, our research interest is the impact of decentralization on one aspect of territorial diversity, specifically on the self-government policy discretion of territories, i.e. on the political autonomy of sub-central governments to make their own policy decisions. But what are the factors that condition the margin for policy discretion of these governments as an expression of their 
political autonomy? The literature has explored several factors that condition policy discretion, such as productive structure, social capital, political culture, government ideology, social capital, political context, budgetary resources, previous policy paths... However, a dichotomy has arisen from the political debate in decentralized States, focusing on two such factors: to what extent are sub-central governments limited in their autonomy by the models of territorial financing, or to what extent do the factors of political will and ideological orientation of those governments primarily determine the direction and scope of their decisions and action? Also, in the academic debate, these same main determinants of the discretion to govern have been identified and explored: the budgetary resources available, on the one hand, and the ideology of the political forces in the government in question, on the other. The influence of resource allocation between levels of government has been studied by the normative principles of fiscal federalism, and the impact of ideology in government decisions has been one of the centres of interest in the literature on public policy.

This research uses these approaches to focus on the experience of decentralization in Spain, where this debate is particularly intense both in political and academic venues, and which may shed light for further comparisons with other decentralized or federal States. Numerous studies have found that, although located in a common legal and institutional framework, the Spanish Autonomous Communities (AC) have expressed their capacity of self-government by taking different public policy options. Since their creation in the early 80 s, the AC have played an essential role as legislators and managers of complex systems of welfare services for citizens. Thus, within their margin of autonomy, the regional governments have developed their own policies of income and spending that have enabled them to develop public management policies that have produced differing models of regulation and service provision $(\mathrm{Gal}-$ lego et al., 2005; Gallego and Subirats, 2011, 2012; Moreno, 2009). Therefore, we ask: Why have regional governments taken different public policy options? In what way, and to what extent, were their policy decisions and actions conditioned by the financing model and by their different ideologies?

To explore this question, we have selected two AC - Catalonia and Andalusia - which are contrasted, among other things, by the options that they have developed for their healthcare models. Healthcare is the budgetary sector with greatest weight in the hands of regional governments (they spend more than a third of their budgets on it), being an essential element of their respective welfare systems. While these $\mathrm{AC}$ show similarity in relation to their political and normative discourses on the right to healthcare and in relation to the levels achieved regarding the extent and intensity of health coverage, numerous studies show that the contrasts are profound if we look at the models for the governance and management in the provision of health 
services: Andalusia reinforced and deployed a system of direct public provision based on an integrated hierarchical model, being built on the model of the structures transferred by the central government; Catalonia set up and consolidated a model of indirect public provision added to the structures of the integrated model transferred by the central government, and which has been based on a contractual network in which the diversity of the legal nature of providers prevails, as well as the interrelationship between public and private healthcare activity. These options for different models of healthcare governance were initially developed under governments of political continuity for more than two decades in both cases: the Spanish Workers' Socialist Party (PSOE) in Andalusia since the first regional elections of 1983 and the centre-right, nationalist Convergència i Unió (CiU) in Catalonia from 1980 to 2003. Moreover, these developments have been accompanied by controversy over the territorial financing model and its impact on the political autonomy of the ACs, which has always been present in the general political debate.

Given this scenario, our study focuses on the first decade of the 2000s, during which we observe decisions by the Andalusian and Catalan regional governments involving changes of direction in their healthcare governance policies. In Catalonia, after more than two decades of consensus on the impossibility of reforming the Catalan Institute of Health (that is, the set of structures for integrated, direct service provision, transferred by the central government), a law was negotiated and approved that transformed it into a public company. In Andalusia the option of transforming the Andalusian Health Service into a public company was rejected and, on the other hand, a network of High Resolution Hospital Centres was developed, with different management formulas and which was external to the prevalent integrated model. Looking at the financing-ideology dichotomy, in both cases, these decisions were made in a context that was expansive in various ways. In late 2001, the transfers of powers to all regions, including healthcare, were completed, although Andalusia and Catalonia had already had this since the early 80 s; and the territorial financing model was modified so that the ACs would increase their resources and earmarking would be eliminated. In addition, the economic environment was upward; therefore, decisions during that decade were not a reaction to the changing economic cycle. In Andalusia such decisions began to be taken prior to 2001 and under continuity of the PSOE in the regional government. In Catalonia such decisions began after the elections of 2003, after an ideological shift in government - namely, by a coalition government of pro-independence forces and leftwing catalanist forces representing the first ideological shift in the Catalan government since 1980. All this gives us a path of broad contrasts and allows us to ask: How can we explain these decisions, again disparate, in the policies of public healthcare management of Andalusia and Catalonia? Are the decisions 
being made highly conditioned by the territorial financing system? Or are they the result of ideological options arising from the exercise of self-government?

This paper addresses these questions by contributing new evidence to the intense debate around the impact of these two variables on the political autonomy of regions in Spain. To do so, it provides a detailed analysis of updated, empirical data that include, on the one hand, the official data on the public resources available to the two ACs being analysed (income coming not only from the territorial financing model, but also from outside it -namely, income decisions by the regional governments themselves), as well as data on their spending decisions. On the other hand, the data analysed include official documents and semi-structured interviews to 20 key officials who either participated in the decisional processes analysed or have expert knowledge about them. The position and number of the interviewees were: senior politicians of the Catalan and Andalusian governments (9), public management and healthcare sector professionals (5), trade union representatives (2), members of non-profit organizations (2) and academic researchers (2). The guidelines of the interviews include the following general topics: characteristics of the health policy sector in both AC, availability and constraints in budgetary resources, intergovernmental relationships and key decisions in health public management (particularly about the Catalan Institute of Health and the network of High Resolution Hospital Centres in Andalusia).

In this paper we present, first, the theories of reference for this approach -fiscal federalism and policy analysis. Second, we analyse the availability of budgetary resources of Andalusia and Catalonia, distinguishing their volume and origin (internal or external to funding model, and tax collection or grants), together with its implications. Third, we explore the influence of the ideology of the political forces in power in each region in order, fourthly, to make a joint interpretation of both cases. We rely on the analytic dialogue between theory and empirical data to then generate an interpretation of the two selected cases. We integrate the interpretation of the influence of both factors - financing and ideology- in these cases, to finally present the findings. Understanding the elements that condition the decision-making processes at these levels of government and, therefore, the nature of their political autonomy, can contribute to comparative knowledge and debate about the operation and functionality of decentralization.

\section{FISCAL FEDERALISM AND POLICY ANALYSIS: THE THEORY OF REFERENCE}

How has the need to decentralize revenue-raising capacity and expenditure of the central government to sub-central governments been argued? The "Oates decentralization theorem" (1972) may be considered the starting point of the 
theory of fiscal federalism, showing that the diversified supply of public goods by sub-central governments provides more welfare (more efficiency) than the uniform supply by a single government, to the extent that a better adjustment of supply to the preferences and needs of each territory occurs. Therefore, the heterogeneity of preferences is one of the main arguments that justify the existence of sub-central governments. The same argument is applied to healthcare, a decentralized function in many States. Therefore, different decisions about the provision of this service would have positive effects on the efficiency, according to the principles of Oates, but could have negative effects on the degree of inter-regional equity, which should be considered (Ayala et al., 2013).

From this point, the question arises: On what criteria should design models for territorial funding be based? According to the main principles of fiscal federalism, the financing model for sub-central government must reconcile the exercise of financial autonomy with a "certain" principle of equity. Thus, revenue sharing must meet the following principles: a) Financial autonomy: all governments should be able to take decisions both on spending (how much and on what they spend) as on income (how much and from where they get their resources). This is only possible if funding is largely not earmarked and comes from own taxes; b) Vertical balance: the different levels of government should have the same degree of coverage of their spending needs; c) Horizontal equity: governments that are part of the same level must have an equal or similar volume of resources to meet their spending responsibilities, asking the same tax effort of their citizens; d) Other principles are transparency, coordination and institutional loyalty.

If the governments of Andalusia and Catalonia have made different decisions in relation to the provision of healthcare, this may be due to at least two reasons. One, the regional governments have provided these services expressing heterogeneous preferences for health output between AC (which supposedly represent the citizens who voted for them) towards a greater collective welfare. Two, the different behaviour of regional governments could be due to the characteristics of the financing model and its results, mainly the available per capita resources, their origin and the decisions that have been taken on them.

In the Spanish case, these options are raised within an institutional framework that is consistent for all regions in certain aspects, such as: the scope of the basic legislation, invasive (or not) effect of the doctrine of the Constitutional Court, the control period of the central administrative unit on the regional territory, the administrative scope or extent of earmarked financing condition the degree of the sub-central government policy autonomy. In this context, key areas of the Welfare State are decentralized to the AC, but framed in equal rights and market unity. That is, the relevance of the various preferences and territorial needs is recognized, but the ultimate responsibility for the provision is preserved by the higher level of government. 
However, from the examination of public policies, other factors are included in the analysis that also influence the development of policies and explain that, even within similar institutional frameworks, sub-central governments make decisions on different public policies. Thus, the ideology of the political forces in power not only results in the construction of a discourse supporting government decisions, but also a priori steers the direction of public policy. The ideology implies a certain identification and definition of the issues to be addressed, bringing a preference for a certain intensity, extent and type of intervention in such issues, and supports the proposal of a particular model of relationship between the external stakeholders and government institutions.

Another factor influencing government action is the nature of the public policy sector in question. This includes, inter alia: the relative weight of public and private provision, management tools used, the characteristics of the sector actors that influence policy making, as well as the type of interaction these have with the political actors. Although these features have a certain structural base, they are also factors that typically become an implicit or explicit object of intervention and modification by government action. Finally, all this unfolds in the context of dynamic contextual aspects of economic, political and social types - both specific for the territory and relevant in a relationship of multilevel governance. Thus, the analysis of capacity constraints and government action necessarily integrates all these factors (financing, ideology and structural and relational characteristics) in the interpretation of the political process.

\section{THE REGIONAL FINANCING MODEL: SAME BUDGET CONSTRAINTS FOR ANDALUSIA AND CATALONIA?}

In the 2000s, the governments of Andalusia and Catalonia took different decisions regarding healthcare. We look at whether these differences can be explained by the characteristics of the financing model. We assume that the model and its evolution have a significant explanatory weight in the political decision-making capacity of regional governments (Vilalta, 2005, 2007; Bosch and Duran, 2008; Bosch and Vilalta, 2008; Ruiz-Huerta et al., 2010) but we want to investigate how and to what extent this influence occurs. So we ask: How does the financing model distribute resources between these territories? Have Andalusia and Catalonia had the same per capita budget? What part of the budgets of the Andalusian and Catalan governments comes from the regional financing model and how much comes from other sources (debt, etc.)?

In accordance with the stated principles of fiscal federalism, we can affirm that the agreed models described below are characterized by: a lack of financial 
autonomy; a lack of global resources to address spending responsibilities; erratic and unjustifiable results according to the principle of horizontal equity.

\section{THE AVAILABILITY AND SOURCE OF RESOURCES DURING THE PERIOD 2001-2011: ARE DIFFERENCES BETWEEN ANDALUSIA AND CATALONIA OBSERVED?}

Andalusia and Catalonia have received resources from the so-called model of financing for the autonomous communities from the common regime. This model has been designed over the last 30 years, the result of successive agreements of the Council of Fiscal and Financial Policy (CPFF). These agreements have been, once the initial stage of transitional funding (1980-1986) had passed, fortnightly. This was so until 2001, when the model was stopped. However, the new Statute of Autonomy of Catalonia, approved in 2006, opened a new negotiation model which was generalized for all the AC in 2009 (that of Andalusia was reformed in 2007 and in regard to the regulation of the financing model, the text is virtually identical to that of Catalonia). Below we describe the operation and the results of agreed models in 2001 and 2009, in force during the period of analysis of this paper.

\subsection{Regional financing agreements of 2001 and 2009}

Catalonia assumes competence in healthcare in 1981 and Andalusia in 1984. Until 2001, only five other autonomous communities had assumed this competence (Andalusia, Galicia and Valencia), as a part of the charter. To finance it, they received a specific grant that for Catalonia was an annual median of 715 euros per capita for the years 1999-2001, and 700 for Andalusia. In 2001, competencies on healthcare was transferred to the other autonomous communities and their financing was integrated into the overall model. All resources will be unconditioned, none of them will have a specific destination.

\subsection{The financing agreement of 2001}

The regional financing model approved in 2001 was designed around two major ways of obtaining revenue: a) the ceded taxes and b) the equalization grant named "sufficiency fund".

a) Ceded taxes

The taxes in the regional governments were: the wealth tax, the gift and inheritance tax, the capital transfers tax, the stamp duty tax, the gambling tax $33 \%$ of personal income tax , 35\% of value added tax (VAT), $40 \%$ of excise duties (tobacco, alcohol and hydrocarbons), the special excise tax on certain 
means of transport, excise duty on electricity, and the excise tax on retail sales of certain hydrocarbons. The first five of these are known by the name of traditional ceded taxes as they were part of the tax basket of regional governments since the early 80 s.

From the beginning, the State transferred the income from taxes, and only in some cases, their management and administration. It would not be until 1996 and especially since the 2001 agreement, when it began also to give some regulatory capacity. Since then, the regional governments have been able to make decisions on certain elements of the following taxes: the aforementioned traditional taxes, income tax, the excise tax on certain means of transport and the excise tax on retail sales of certain hydrocarbons ${ }^{1}$.

Ceded taxes is complemented by the so-called own taxes. Regional governments can create tax figures provided they do not reflect taxable events already recorded by the central government. This has been used to establish taxes that, in general terms, either have an environmental objective or fall on gaming. The AC have used this possibility with different intensity. Catalonia has been a very active community in the creation of own taxes. On the other hand, the application of these tax forms has often led to legal conflict with the central government.

b) The equalization grant: The sufficiency fund

The AC receive a grant called the sufficiency fund. The distribution of the fund is carried out based on expenditure needs. To quantify them a set of variables (population, area, scatter, relative income, population over 65 years, insularity) is used, and specific funds, guarantees and modulation rules are organized ${ }^{2}$.

Table 1 shows the result of the model financing agreement in its first and last year of validity. The differences between Catalonia and Andalusia fall both in the volume of per capita resources provided by the model, and in its origin. In 2008, the model brings to Catalonia 81 euros per capita less than that received by Andalusia. In Catalonia, $88 \%$ of resources come from ceded taxes, however, in Andalusia, this percentage is $55 \%$. The weight of the sufficiency fund is therefore greater in Andalusia than in Catalonia.

\subsection{The financing agreement of 2009}

The model agreed in 2009 includes three income methods: a) Ceded taxes; b) An equalization mechanism; c) The adjustment funds.

\footnotetext{
1 For a detailed explanation of the regulatory power of the AC on each of the tax, see Bassols et al. (2010: 9-12, 31-35).

2 For more detail, see Gallego (2014: 38-42).
} 


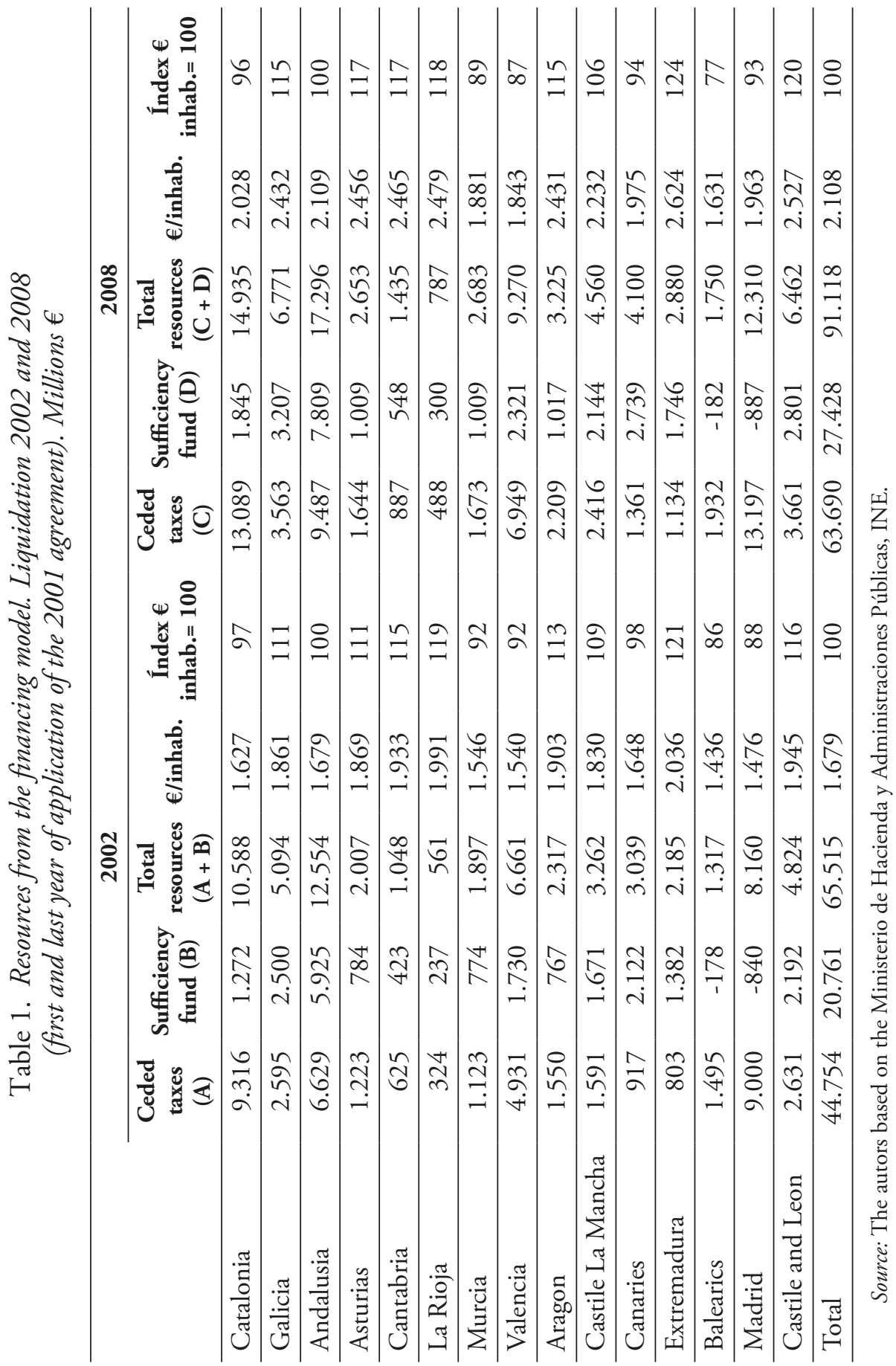


a) Ceded taxes

Compared to the previous model, the percentages of assignment of the main tax types are extended: the personal income tax from 33\% to $50 \%$; VAT from $35 \%$ to $50 \%$ and excise taxes from $40 \%$ to $58 \%$.

b) The equalization mechanism

To comply with the principle of equity, an equalization grant is made up, called the "guarantee fund for basic public services" (FGSPF). The aim is to ensure that each region receives the same resources per capita (adjusted) to fund essential services of the Welfare State (education, health and social services), undertaking the same tax effort ${ }^{3}$. As shown in column 2 of Table 2, there are regions that are providers to the FGSPF (e.g. Catalonia) and others that are receivers (e.g. Andalusia). In 2011, Catalonia contributed 1,020 million euros to this fund and Andalusia received 3,556.

\section{c) The adjustment funds of the model}

The model contains three further funds that deviate from the objective of equalization corresponding to the FGSPF. They are funds derived from political negotiation and the implicit aim of maintaining the status quo, despite the change of model.

Table 2 also shows the final result of applying the funding model in 2011. The ceded taxes provided Catalonia 17,578 million euros and 13,173 million euros for Andalusia. If to this amount are added and/or subtracted funds of the model (the FGSPF and the three adjustment funds), Catalonia ends up receiving 19,076 million euros and Andalusia 18,653 million euros. In euros per inhabitant expressed as an index it stands at 99 for Catalonia and at 94 for Andalusia.

Finally, if the development of resources from the financing model over the analysed period is observed, it can be seen that the 2001 model always provided more resources per capita to Andalusia than to Catalonia, however, starting from the 2009 agreement, receipts per capita for Andalusia are lower than those for Catalonia (see Figure 1 in Annex). This shows that in the last agreed model, the government that has a higher fiscal capacity (higher tax bases) will have more resources per capita than the one that has a lower fiscal capacity. Which is consistent with a partial equalization mechanism (Boadway and Flatters, 1982).

3 For more detail, see Bassols et al. (2010: 37-38). 
Table 2. Resources from the funding model. Liquidation 2011. Millions $€$

\begin{tabular}{lrrrrrr}
\hline & $\begin{array}{c}\text { Ceded } \\
\text { taxes }\end{array}$ & FGSPF & $\begin{array}{c}\text { Adjustment } \\
\text { funds }\end{array}$ & Total & €/inhab. & Index \\
\hline Catalonia & 17.578 & -1.020 & 2.518 & 19.076 & 2.243 & 99 \\
\hline Galicia & 4.987 & 1.087 & 1.192 & 7.267 & 2.504 & 111 \\
\hline Andalusia & 13.173 & 3.556 & 1.924 & 18.653 & 2.120 & 94 \\
\hline Asturias & 2.257 & 134 & 421 & 2.812 & 2.542 & 113 \\
\hline Cantabria & 1.328 & -33 & 482 & 1.778 & 2.807 & 124 \\
\hline La Rioja & 652 & 46 & 229 & 927 & 2.724 & 121 \\
\hline Murcia & 2.403 & 537 & 165 & 3.106 & 2.102 & 93 \\
\hline Valencia & 9.387 & 1.147 & 559 & 11.093 & 2.113 & 94 \\
\hline Aragon & 3.020 & 40 & 550 & 3.610 & 2.626 & 116 \\
\hline Castile La Mancha & 3.537 & 958 & 453 & 4.948 & 2.334 & 103 \\
\hline Canaries & 1.758 & 2.264 & 454 & 4.476 & 1.992 & 88 \\
\hline Extremadura & 1.654 & 657 & 563 & 2.874 & 2.585 & 115 \\
\hline Balearics & 2.651 & -179 & 160 & 2.632 & 2.275 & 101 \\
\hline Madrid & 17.041 & -2.794 & 647 & 14.894 & 2.154 & 95 \\
\hline Castile and Leon & 5.081 & 651 & 996 & 6.727 & 2.625 & 116 \\
\hline Total & 86.506 & 7.053 & 11.314 & 104.873 & 2.257 & 100 \\
\hline
\end{tabular}

Source: The autors based on the Ministerio de Hacienda y Administraciones Públicas, INE.

However, we must clarify that this set of tax revenues provided by the model does not include the tax collection effects due to the use that the AC can make of available regulatory capacity on the different ceded taxes, both to reduce and to increase them. In this sense, the central regulation of assigned taxes acts as a subsidiary, i.e. if the autonomous community does not regulate them, it will obtain revenues as if it applied central regulations ${ }^{4}$.

Table 3 shows how the trend has been in the use of the regulatory capacity on the main ceded taxes by the AC throughout the period. Although this use of the regulatory capacity has effects in collection that are difficult to quantify, the impact column tries to show some evidence on the magnitude of these effects.

4 However, from 2011, if an autonomous community does not approve the regional rate of income tax, the subsidiary central rate is not applicable but rather there arises a situation of absence of regional tax and of the regional tax receipts. This measure was intended to encourage the responsibility of regional governments when taking and updating their fiscal decisions and also to be accountable to their contributors. 


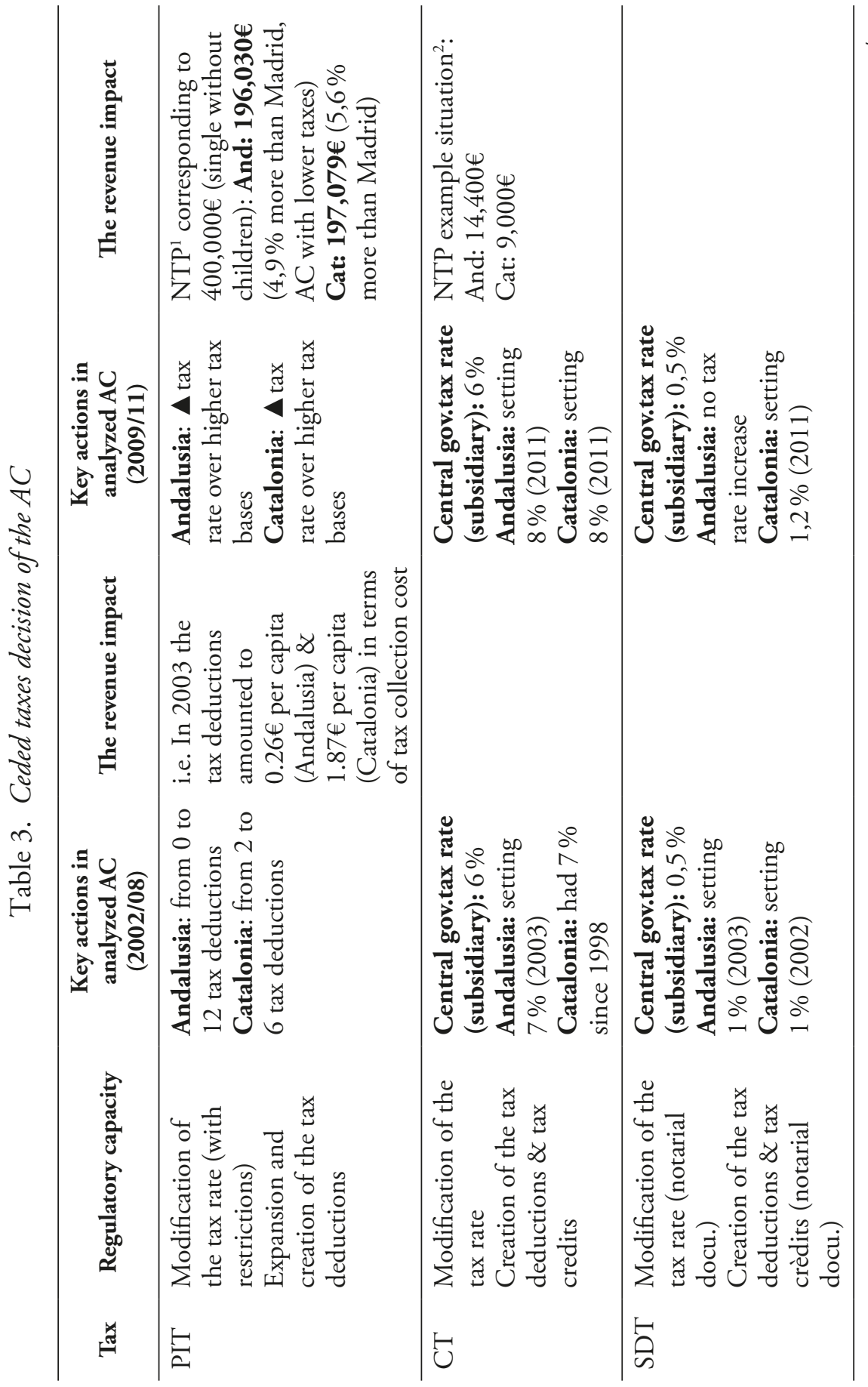




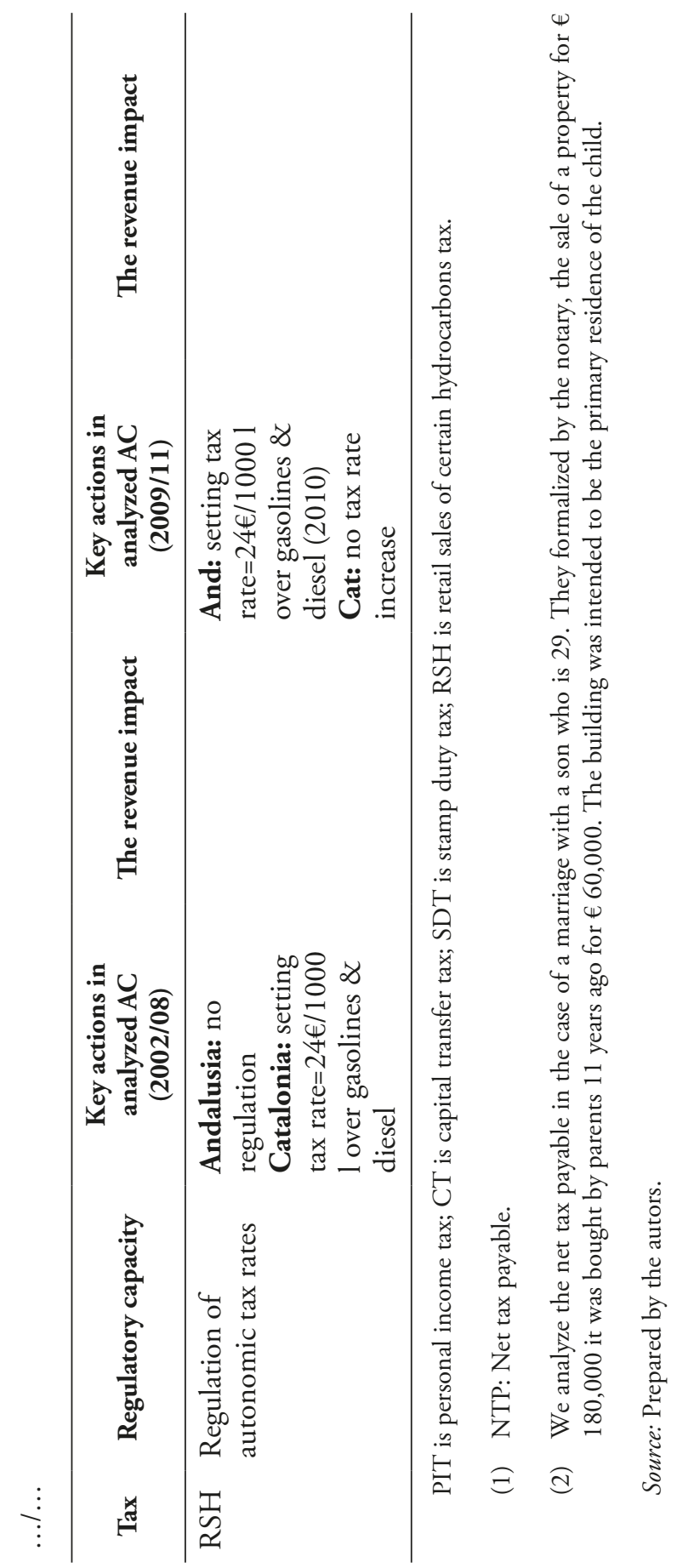




\section{BEYOND THE RESOURCES FROM THE FUNDING MODEL}

Not all regional government revenues come from the funding model. There are others, such as: public fees and charges; income from the use or sale of public assets; transfers of private companies, the European Union or also the central government, which are not part of the model; financial operations. In Andalusia the weight of resources coming from the model in relation to total income is higher than in Catalonia: $62 \%$ vs. $59 \%$ (average 2002/08) and $55 \%$ vs. $49 \%$ (average $2009 / 11$ ).

While per capita resources from model have been, during the years 20012008, higher in Andalusia than in Catalonia, in the end both regions end up having a similar volume of total resources per inhabitant. Catalonia has had to find, then, a greater share of its income from outside the model (see Figure 2 in Annex).

Table 4 shows the behaviour of the sources of income from outside the funding model. The main differences are observed in: i) Financial transactions: Catalonia has borrowed more than Andalucía (an annual average of 588.79 euros per inhabitant and 232.93, respectively) during the period 2002-2011; ii) transfers or grants: Andalusia has received more grants than Catalonia (an annual average per capita of 598.33 euros and 334.86, respectively). When a large part of a government's income comes from grants, this may have undesirable effects, linked to the existence of a "fiscal illusion", that is, the non-perception by citizens of the true "cost" of services which they receive from their government (see Boadway and Flatters, 1982; Lago, 2002; Esteller, 2005).

Table 4. Income sources out of the funding model. Average 2002-2011. € per inhabitant

\begin{tabular}{lcrrr}
\hline & \multicolumn{2}{c}{ Andalusia } & \multicolumn{2}{c}{ Catalonia } \\
\cline { 2 - 5 } & $\begin{array}{c}€ \\
\text { inhabitant }\end{array}$ & \multicolumn{1}{c}{$\%$} & $\begin{array}{c}€ \\
\text { inhabitant }\end{array}$ & \multicolumn{1}{c}{$\%$} \\
\hline User fees, public prices, special taxes & 82,28 & $8,8 \%$ & 103,00 & $9,9 \%$ \\
\hline Income assets & 14,20 & $1,5 \%$ & 3,18 & $0,3 \%$ \\
\hline Sale of real investments & 3,50 & $0,4 \%$ & 5,54 & $0,5 \%$ \\
\hline Transfers* & 598,33 & $64,3 \%$ & 334,86 & $32,3 \%$ \\
\hline Financial operations & 232,93 & $25,0 \%$ & 588,79 & $56,9 \%$ \\
\hline Total revenue "outside the model" & 931,23 & $100,0 \%$ & $1.035,36$ & $100,0 \%$ \\
\hline Total revenue & $3.458,00$ & $371,3 \%$ & $3.662,00$ & $353,7 \%$ \\
\hline
\end{tabular}

* Transfers from central government (out of model), from privat firms and non-profit institutions, and from outside the country.

Source: The autors based on the Ministerio de Hacienda y Administraciones Públicas, INE. 


\section{HEALTH POLICY DECISIONS IN ANDALUSIA AND CATALONIA: THE INFLUENCE OF IDEOLOGY?}

Regarding the influence of ideology as a conditioning factor of government capacity we ask, for the decade under investigation: What was the per capita health budget in Andalusia and Catalonia? How have these autonomous communities structured their health spending? What model of service delivery and management has been developed in each?

\section{MANAGING THE BUDGET: SPENDING DECISIONS AS POLICY DECISIONS}

Health expenditure per capita has generally increased over the period although a change in trend is observed as from 2008 (see Figure 3 in Annex). Several authors relate this increase to the decentralization of healthcare referring to aspects such as: competition between $\mathrm{AC}$, the possible increase of prices of factors due to fragmentation of purchasing power, the existence of interest groups with great regional power, or export of innovation processes and measures to other communities that may ultimately mean more costs (Costa-Font and Pons-Novell, 2007; Cantarero and Lago, 2010; Urbanos, 2006). In 2011, national average per capita healthcare expenditure stands at 1,322 euros, much like that of Catalonia $(1,342)$ and above that of Andalusia $(1,121)$.

Regarding the economic nature of healthcare spending by the communities (Table 5), the difference is observed in the model of provision of healthcare between Andalusia and Catalonia. In the case of Andalusia, the component with greater weight is staff remuneration ( $47 \%-49 \%)$ followed by current transfers (24\%-24\%), and intermediate consumption - materials, supplies, etc. (21\%-20\%). In Catalonia, in the period 2002/08, expenditure on purchases from the private sector through special agreements have the most weight $(33 \%)$, followed by remuneration of staff $(28 \%)$ and current transfers $(22 \%)$. Although the weight of the private sector agreements decreases in the following period, we can say that the figures reflect the presence of a large number of private providers in the Catalan model.

The quantitative importance of the section on "current transfers" that includes mainly expenditure for pharmaceutical services should also be highlighted $^{5}$. These costs represent the average for the period 2009/2011:280 euro per capita in Andalusia and 255 per capita in Catalonia.

5 The concept of current transfers mainly reflects spending on prescriptions and reimbursements for prostheses and therapeutic devices. 
Table 5. Health public expenditure. Economic nature

\begin{tabular}{lcccc}
\hline & \multicolumn{2}{c}{ Andalusia } & \multicolumn{2}{c}{ Catalonia } \\
\cline { 2 - 5 } & $\mathbf{2 0 0 2 / 0 8}$ & $\mathbf{2 0 0 9 / 1 1}$ & $\mathbf{2 0 0 2 / 0 8}$ & $\mathbf{2 0 0 9 / 1 1}$ \\
\hline Staff remuneration & $47 \%$ & $49 \%$ & $28 \%$ & $36 \%$ \\
\hline Intermediate consumption & $21 \%$ & $20 \%$ & $14 \%$ & $18 \%$ \\
\hline Agreements & $5 \%$ & $5 \%$ & $33 \%$ & $24 \%$ \\
\hline Current transfers & $24 \%$ & $24 \%$ & $22 \%$ & $18 \%$ \\
\hline Capital costs & $3 \%$ & $2 \%$ & $3 \%$ & $3 \%$ \\
\hline Consumption of fixed capital & $0 \%$ & $0 \%$ & $0 \%$ & $1 \%$ \\
\hline Total health public expenditure & 100 & 100 & 100 & 100 \\
\hline
\end{tabular}

Source: the autors based on Ministerio de Sanidad, Servicios Sociales e Igualdad.

Table 6 gives us an approximate idea of the strategic direction of healthcare policy in each community. As can be seen, more than half of healthcare expenditure in the communities is intended for "hospital and specialized care", the second function in order of importance is spending for "pharmacy", despite the decline that this has recorded in its share of the total between 2002 and 2011.

Table 6. Health public expenditure. Functional classification

\begin{tabular}{lllll}
\hline & Andalusia & \multicolumn{3}{l}{ Catalonia } \\
\hline & 2002 & 2011 & 2002 & 2011 \\
\hline Hospital and specialist services & $53 \%$ & $57 \%$ & $53 \%$ & $60 \%$ \\
\hline Primary care & $17 \%$ & $17 \%$ & $15 \%$ & $14 \%$ \\
\hline Public care services & $0 \%$ & $0 \%$ & $0 \%$ & $1 \%$ \\
\hline Collective care services & $1 \%$ & $1 \%$ & $4 \%$ & $3 \%$ \\
\hline Pharmaceuticals & $25 \%$ & $21 \%$ & $24 \%$ & $17 \%$ \\
\hline $\begin{array}{l}\text { Moving, prothesis \& } \\
\text { therapeutic aparatus }\end{array}$ & $2 \%$ & $2 \%$ & $2 \%$ & $3 \%$ \\
\hline Capital costs & $2 \%$ & $1 \%$ & $2 \%$ & $3 \%$ \\
\hline Total health public expenditure & 100 & 100 & 100 & 100 \\
\hline
\end{tabular}

Source: The autors based on Ministerio de Sanidad, Servicios Sociales e Igualdad. 
In Catalonia, the costs associated with hospital and specialist services have gone from 53\% (2002) to 60\% (2011), a figure which represents 802 euros per capita, above the 643 per capita in the case of Andalusia. Likewise, the relative weight of spending on primary care has suffered slight variation in the analysed period representing in 2011: 193 euros per capita in Andalusia and 182 in Catalonia.

\section{CHANGING HEALTH PUBLIC MANAGEMENT: WHY AND HOW?}

\subsection{Catalonia: Formulating the Law of the Catalan Health Institute}

The trajectory of the health policy in Catalonia over the last two decades of the $20^{\text {th }}$ Century has been widely analyzed (Gallego, 2000, 2016). Catalonia was the first Autonomous Community to receive the health policy competencies in 1981, at the onset of the devolution process. The public providers transferred by the Spanish government to the Catalan government were all integrated into a single organization - the Catalan Health Institute (ICS)_- preserving and replicating the Spanish direct public provision. These providers amounted to over 90 per cent of primary care providers in Catalonia, but only to a third of the hospital beds at that time, which left scope for contracts with external providers to play a prominent role. In this scenario, the Catalan government gradually consolidated a contract-based health provision system that built on pre-existing private (both profit and non-profit) and public providers, most of which required considerable investment to become technically and economically viable. Building on them, the Catalan health system developed an extensive, publicly funded, indirect provision model (arm's length relationship between purchaser and provider), with a complex network of providers of different public and private ownership formulae (Gallego and Subirats, 2012; Gallego et al., 2005). With the 1990 Law of Organization of Health in Catalonia, the ICS lost the purchasing functions it had had vis-à-vis de contracted network. Those functions were assigned to a newly created health authority body that would act under private management regulations - The Catalan Health Service (SCS)_-, what mitigated the rest of providers' mistrust for it being both purchaser and provider. Meanwhile, the ICS remained as an isolated exemplar of direct, public provision: a large provider of health services, with a single legal personality, operating under administrative law regulations. As a result, it was persistently seen as an isle of obsolete privilege by the contracted providers, particularly in relation to the different regulation of labour relations (largely civil service) and financing mechanisms (budget allocations). 
The need to reformulate of the ICS's legal nature, the criticisms about its inefficiency, and the insistence on the need to modernize its management tools had been permanent issues in the discourse of a large part of actors related to the Catalan health policy sector (politicians, managers and professionals), attracting varying degrees of attention throughout that time. However, these studies also highlight that these same actors considered that such changes had not been addressed over those years because: a) from a legal point of view, it was very difficult to change regulations from a Social Security management body form to a Publicly-Owned Enterprise or to Autonomous Body forms; b) the Ministry of Economy and Finance of the Catalan government, and particularly its Intervention Unit, due to the institutional bias derived from its control role, opposed a management model that might involve ex post economic and financial control; and c) unions would probably mobilize a strong professional opposition if that proposal involved a change in labour relations. Some arguments also pointed out that a legal redefinition of the ICS required an injection of economic resources (to balance budgets) that could not be affordable by the budget of the Catalan government.

The Catalan regional elections of November 2003 brought the first ideological turnover in the Catalan government since the Spanish democratic transition of the late 1970s. The nationalist, center-right party coalition Convergència i Unió $(\mathrm{CiU})$ had ruled the Catalan government over 23 consecutive years, since the first regional election in 1980, and with an absolute majority between 1984 and 1995 . As a result of the 2003 Catalan elections a post-electoral centre-left coalition formed to add-up to an absolute majority in parliament and took office: the Party of the Socialists of Catalonia (PSC), the independentist Republican Left of Catalonia (ERC), and the eco-socialist coalition Initiative of Catalonia-Green (ICV), each of them representing different intensities of Catalan nationalist and leftist leanings.

The post-electoral agreement that was the base for the tripartite government made an explicit political option for strengthening social policy in general, and health policy in particular, with a wide support for the modernization and sustainability of public services. The Minister for Health (Marina Geli, from PSC) appointed by the new Catalan president (Pasqual Maragall, from PSC) was committed to push important changes in the health arena. As she announced in her fist address to Parliament, during her mandate, she would prioritize two laws: the Decree of Health Territorial Governments, which was passed at the beginning of 2006; and the Law on Public Health, which was passed in 2009. As a reinforcing piece of the government program, Geli announced third law, the ICS's Law. She said she would promote a different view of ICS and made her intention explicit to address the ICS's modernization through a change in its legal nature and the improvement of its 
management tools and autonomy, with an aim to make it closer to the way of operating of the contracted providers, all with an aim to ensure its sustainability.

The negotiations of the ICS Law started at the beginning of 2004 and were extended into the following legislative period, also under the tripartite government, to be passed in mid-2007. This Law transformed the ICS from an administrative body into a public enterprise with the corresponding change in the public management model. The negotiations centred on four issues: legal personality, degree of financial autonomy, (non-)civil service status of health professionals, and degree of organizational unity or disaggregation. The result of the negotiation led to the creation of a public enterprise which would be committed to a permanent auditing with the Catalan Ministry of Economy. This commitment meant an increase in the existing ICS's financial and accounting autonomy, but which would be lower than that usually enjoyed by public companies. Third, an agreement was reached with the trade unions in which the government would not change the employment civil service status of ICS's staff. There would be the possibility of contracting new staff with non-civil service status, but only in certain circumstances and as an exception. And, finally, among the different options about organizational unity, the alternative chosen was transforming the ICS into a unitary public company, so its provider units (hospitals and primary care centres) would not have independent legal personality.

After 2010 the political map of Catalonia changed. CiU won the Catalan elections again and Boi Ruiz, coming from the Catalan Union of Hospitals (representing managerial interests from contracted providers) was appointed as the new Minister of Health of the Catalan government. Prominent among the first political decisions of the new government was the Omnibus Law. This law meant the simultaneous modifications of a large number of previous laws, including the ICS' law. Having only the support of the Popular Party, CiU approved mechanisms for disaggregating the ICS into its provider units, for offering ICS's infrastructures for contract to private health companies, and for expanding the use of labour contracts not based on civil service conditions.

\subsection{Andalusia: Expanding the network of Hospital Centres of High Resolution}

Since Andalusia received the competencies on health care in 1984, its healthcare system preserved the public, integrated, direct provision model as it was initially transferred by the Spanish government. In a region where at that time private actors did not exist in health care provision —only some religious entities offered charity healthcare services-, the Andalusian government 
centralized the health care system almost exclusively to one organization: the Andalusian Health Service (SAS) (MSPSI 2010). This autonomous, administrative organization performed planning, contracting, and health service provision roles in the areas of both primary and hospital care. The SAS was under the jurisdiction of the Ministry of Health of the Andalusian government, but the role of the ministry was limited and its functions were not clearly differentiated from those of a number of SAS departments.

The continuation of the Spanish Workers' Socialist Party's (PSOE) in the Andalusian government since the first regional elections of 1982 - occasionally with an absolute majority - resulted in healthcare policy decisions that were supported by government majorities — and less by parliamentary consensus - as well as by ideological preferences. Criticisms to the inefficiency of the integrated, direct public provision model were recurrent, but much linked to the same arguments also highlighted in the rest of regions in relation to the integrated model -such as, contending interpretations about the level of discretion of health professionals and managers in terms of spending, red-tape and managerial inefficiency.

The consolidation of this model, though, did not prevent the regional government from exploring the introduction of organizational innovations towards the end of the decade of the 1990s (Martín, 2003; Palomo et al., 2012). On the one hand, these innovations included individual legal personification through the creation of a small number of State-owned companies outside SAS, and on the other hand, few punctual agreements with the few existing private entities - both for-profit and non-profit - for the provision of hospital care. In this sense, the Law on the Health of Andalusia (1998) laid the foundations for a possible - and future- separation of functions between the Department of Health and SAS. In 1999 SAS published its Strategic Plan, entitled "A differentiated proposal of public management" (Torrubia and Higuera, 2011), which recommended the introduction of clinical and administrative management strategies. During the 1990s, global changes in SAS were also explored but were ruled out, such as, for example, the conversion of the organisation into a State-owned company. However, none of these processes at the time involved structural changes in the management of the healthcare system, although they did form the basis for institutional changes put in place at the beginning of the 2000s.

During the first decade of the 2000s the Andalusian Health System was characterized by being based on a public and direct provision and having SAS as the main actor. However, the changes in the Andalusian public healthcare system during that time were numerous and diverse - including quality strategy, a clinical management model, and a change in labour policy at SAS, among other initiatives. 
There were also important changes in the structure of service provision through the network of new hospitals created by the regional government, with unique characteristics. This was a decentralized network of High Resolution Hospitals (CHAREs) that took on the legal status of State-owned companies and was gradually developed through the whole decade. The aim of these hospitals, which are smaller than SAS hospitals, was to improve access to and efficiency of the healthcare system. The legal status of State-owned company (and the resultant regulations) had been introduced originally during the 1990s but it was at the beginning of the 2000s that were undertaken as the preferred form for the expansion of service provision. Formally, these regulations remained unchanged, although they were interpreted and enacted in new ways. This meant the consolidation of the legal status developed during the 90s but not the introduction of changes on labour conditions of existing workers (civil servants), but the contract of new professionals under new conditions (labour staff). The public officials interviewed for this study point to this decision as the main argument for unions - the only organized stakeholder - to support this initiative. The government decided that the CHAREs would organically depend on the Department of Health — just like the existing State-owned companies — and not on the SAS, a decision that reinforced the government's general aim of separating, at least in part, the functions of these two organizations. According to the top-officials interviewed, the decision to develop the CHAREs network under the legal status of State-owned companies did not involve opting for a management model different to the integrated SAS, but reflected the need to improve the efficiency of the public system. However, the Andalusian government continued to construct different types of hospitals that organically depended on SAS, what implies the search of balance between different models of provision ${ }^{6}$.

In short, policymakers interviewed for this study conceived and justified the decision to develop the CHAREs network as an alternative to cooperation with private centres and, also, an attempt to demonstrate that private management was not more efficient than public management. The CHAREs network was at the same time an opportunity to reinforce — and completethe model of direct public service provision, as well as to drive changes in the global governance of the healthcare system.

6 At the same time, it is important to bear in mind that the concept of the State-owned company has become increasingly ambiguous since its introduction in Andalusia in the 1990s: it implies greater administrative flexibility but also allows a certain level of political control. In turn, after the period analyzed in this case study, the legal figure of public firm adopted by CHARES was transformed into public firm agency (Law 1/2011, of Reorganization of the Andalusian Public Sector). 


\section{FINANCING MODEL AND IDEOLOGY: HOW DO THEY INFLUENCE REGIONAL POLITICAL AUTONOMY?}

After more than two decades in which Andalusia and Catalonia consolidated different models of public healthcare provision, in the early 2000s, their governments undertook reforms in this area which again were different. Andalusia boosted the CHAREs bringing public governance closer to private management instruments, but consolidated and strengthened the model of direct public provision of SAS. Catalonia maintained the contracted network, but transformed the ICS direct public provision into a public company. These decisions again different; do they respond to an ideological option or have they been conditioned or constrained by the territorial funding model?

The period analysed in this study is part of an upward and expansive economic cycle for both regions. Catalonia and Andalusia had the same level of competence in healthcare provision since the early 1980s. In the analysed period, the reforms of the territorial funding model of 2001 and 2009 expanded their powers of income and expenditure and increased the volume of their available budgetary resources - both for those coming from the territorial funding model and for those from outside the model. This allowed the per capita healthcare expenditure to increase exponentially until 2008 in Andalusia and until 2010 in Catalonia, then a descent began, linked to the crisis. However, until 2008, Catalonia received annually fewer resources per capita than Andalusia from the funding model, accentuating the difference until the reform of the model in 2009 reversed this situation. According to officials interviewed for this study, increasing available resources always facilitated the proposal for reforms, and, as they indicate, in both cases the proposed reforms required increased resources. Throughout the decade under study, the relative weight of resources from the funding model to total revenues of the regional government has been greater in Andalusia than in Catalonia, and in both cases this weight has decreased since 2009. In the budgets, for 2008, allocated income taxes represented $88 \%$ of revenues in Catalonia and $55 \%$ in Andalusia, making the latter more dependent on transfers or grants from other levels of government. In any case, resources per capita in both AC were finally similar, because Catalonia resorted to financing from outside the model.

The greater weight of taxes and debt implies greater responsibility in accountability, and it is relevant to note that, throughout the period, healthcare spending per capita has been higher in Catalonia than in Andalusia. Also, the structure of health spending reveals a policy option for different delivery models. In Andalusia, the remuneration of staff and intermediate consumption has increased from $68 \%$ to $69 \%$ of total spending, indicating that the weight of the 
integrated model (direct public provision) has not changed despite the analysed reform. In Catalonia, the weight of the integrated model (remuneration of personnel and intermediate consumption) has increased from $42 \%$ to $54 \%$ of total health expenditure, while the weight of the model of indirect provision (private partnerships) has decreased from $33 \%$ to $24 \%$. This indicates a strengthening of the direct public provision model following the reform and throughout the period. Therefore, budget data indicate that in both cases the reform reinforced the model of direct public provision, which fits with the discourse of its promoters in both cases, but not with the diversification of management involving both the CHAREs as well as the conversion of ICS to a public company.

The influence of the ideology factor also raises ambiguities, particularly regarding the link between propositional principles traditionally assigned to ideologies on the left-right axis, on the one hand, and the programmatic proposals and government actions of the parties, on the other. During the last two decades of the $\mathrm{xx}^{\text {th }}$ century, Andalusia was ruled by a leftist party (PSOE) and Catalonia by a nationalist coalition of the centre-right $(\mathrm{CiU})$. This would strengthen the traditional bond of leftist ideology with a model of direct public provision in an integrated structure (Andalusia) and a right-wing ideology with a model of indirect public provision (Catalonia). However, in early 2000, in Andalusia there is continuity of the PSOE in government but they undertake reforms that involve the diversification of forms of management and distancing from the integrated model. In Catalonia, there is an ideological shift to the left in government (PSC-ERC-IC), but the new government does not question the contractual delivery network and transforms the single integrated structure of the healthcare system - the ICS — into a public company, away from the integrated model and opening the door to disaggregation and indirect public provision in the ICS space.

However, if we understand ideology as a complex link between principles and interests expressed through a programmatic and justifying discourse of government action, the analysis of these cases shows that ideology has a great influence on government decisions and if the scope of government action is not well determined - being limited by available resources - it does determine its direction. Therefore, as seen in these two cases, reforms of healthcare management that choose management tools that depart from direct public provision or integrated model do not necessarily imply an ideological shift to the withdrawal of the public sector in the provision of services, but rather that budget indicators can reveal the reinforcement thereof. The officials interviewed for this study insist in the political will for this, whether or not it be the case. Moreover, they explicitly insist that not only are they moving in an ideological axis of left and right, but also in a territorial centre-periphery axis that shows in each case projects other than identity affirmation. 


\section{CONCLUSIONS}

The interest of this research is the impact of decentralization of States on the political autonomy of sub-central governments. In both academic and political debates on the factors that condition the policy discretion of those governments, there are voices that highlight the model of regional financing and voices that insist on the political will and the ideological orientation of parties in power, as alternative explanations. To explore this question, this article presents a study in decentralised Spain, on: Why have regional governments taken different public policy options? In what way, and to what extent, were their policy decisions and actions conditioned by the financing model and by their different ideologies? Theories on fiscal federalism and theories of public policy analysis have guided the analysis.

We selected the regions of Andalusia and Catalonia where, after more than two decades in which they consolidated different models of public healthcare provision, in the early 2000s, their governments undertook reforms in this area which again were different. Andalusia boosted the CHAREs bringing public governance closer to private management instruments, but consolidated and strengthened the model of direct public provision of SAS. Catalonia maintained the contracted network, but transformed the ICS direct public provision into a public company. Do these decisions respond to an ideological option or have they been conditioned or constrained by the territorial funding model?

In a context of upward economic cycle, in 2001 the territorial financing model was modified so that the CA increased their resources and the economic transfers they received from the central government for health were no longer earmarked. The analysis of the evolution of resources from the territorial funding model shows that the model approved in 2001 always provided more resources per capita to Andalusia than to Catalonia and, instead, starting from the agreement of 2009, this situation was reversed. Thus, while per capita resources from the model have been, during the years 2001-2008, higher in Andalusia than in Catalonia, in the end both regions end up having a similar volume of resources per inhabitant. Catalonia has therefore sought a greater share of its income from outside the model (higher debt and greater use of its regulatory powers over taxation) and, from 2005, health spending per capita in Catalonia has tended to be higher than in Andalusia. Key officials interviewed for this study agree in interpreting that the widespread increase in resources facilitated the reforms undertaken in both AC, that is, the scope of government action. In Catalonia, a reform that had been considered by actors of all ideological lines as unapproachable for more than two decades was undertaken, and in Andalusia, a reform that had hardly been considered in previous years was deployed. 
Faced with the different orientation of these reforms, these sources also agree that, as in previous decades, the content and direction of them respond to the political preferences of the political forces in government. However, the influence of the ideological factor in these decisions does not provide conclusive evidence: in Andalusia, under the continuity of the PSOE, there are reforms that involve the diversification of forms of management and their distancing from the integrated model — which does not fit the traditional preference of the left for the model of direct public provision that had been defended until then-; in Catalonia, there is an ideological shift to the left in the government, but the new government does not question the contractual provision network and transforms the single integrated structure of the healthcare system into a public company, thus moving away from the integrated model and opening the door to disaggregation and indirect public provision in that space.

These results confirm that the nature and volume of budgetary resources of sub-central governments determine the extent of political autonomy, but not its direction, which would be marked by ideological choices. However, these findings raise new questions. According to the theories of fiscal federalism, greater weight of own resources in the budget as opposed to transfers/ grants from other governments brings a greater responsibility for accountability towards citizens. But to what extent are citizens and public decision makers themselves aware of the degree of dependence on their resources? Finally, according to the political theories, right and left tend to identify with certain options of management models; but when the evidence does not show it to be so, does the management model stop being ideologically relevant?

\section{Acknowledgements}

This paper integrates results from two research projects, one funded by the Ministry of Science and Innovation of the Spanish government (CSO201127547) and another one funded by the Catalan government (Ordre GRI/6/2012, July 20).

\section{Bibliography}

Ayala, L., Martínez, R. and Ruíz-Huerta, J. (2013). Desigualdad y redistribución en los países de la OCDE. En Informe sobre la desigualdad en España (pp. 25-73). Madrid: Fundación Alternativas,.

Bassols, M., Bosch, N. and Vilalta, M. (2010). El model de finançament autonòmic de 2009: funcionament i valoració. Barcelona: Generalitat de Catalunya, Departament d'Economia i Finances. 
Boadway, R. and Flatters, F. (1982). Efficiency and Equalization payments in a federal system of government: a synthesis an extension of recent results. The Canadian Journal of Economics, 15 (4), 613-633. Available at: https://doi.org/10.2307/134918.

Bosch, N. and Durán, J. M. (eds.). (2008). Fiscal Federalism and Political Decentralization. Lessons from Spain, Germany and Canada. Chentelham: Edward Elgar. Available at: https:// doi.org/10.4337/9781848442719.

— and Vilalta, M. (2008). Informe sobre el finançament de les comunitats autònomes. Any 2006. Barcelona: Generalitat de Catalunya, Departament d'Economia i Finances.

Cantarero, D. and Lago-Peñas, S. (2010). The determinants of health care expenditure: a reexamination. Applied Economics Letters, 17 (7), 723-726. Available at: https://doi. org/10.1080/13504850802314437.

Costa-Font, J. and Pons-Novell, J. (2007). Public health expenditure and spatial interactions in a decentralized national health system. Health Economics, 16 (3), 291-306. Available at: https://doi.org/10.1002/hec.1154.

Esteller, A. (2005). Is there a connection between the tax administration and the political power? International Tax and Public Finance, 12 (5), 639-663. Available at: https://doi. org/10.1007/s10797-005-2651-5.

Gallego, R. (2000). Introducing Purchaser/Provider Separation in the Catalan Health Administration: A budget analysis. Public Administration, 78 (2), 423-442. Available at: https://doi.org/10.1111/1467-9299.00213.

— Gomà, R. and Subirats, J. (2005). Spain, from State Welfare to Regional Welfare. En N. McEwen y L. Moreno (eds.). The Territorial Politics of Welfare (pp.103-126). London: Routledge.

— (dir.). (2014). Descentralització i autonomia politica: L’impacte de la ideologia $i$ el finançament territorial en els models sanitaris de Catalunya i Andalusia. Barcelona: Institut d'Estudis Autonòmics.

— (dir.). (2016). Descentralización y desigualdad en el estado autonómico. Valencia: Tirant lo Blanch.

— and Subirats, J. (2011). Regional welfare regimes and multilevel governance. En A. M. Guillén y M. León (eds.). The Spanish welfare state in the European context (pp. 97-118). Oxon: Routledge.

- (2012). Spanish Regional and Welfare Systems: Policy Innovation and Multi-level Governance. Regional and Federal Studies, 22 (3), 269-288. Available at: https://doi.org /10.1080/13597566.2012.688271.

Guillén, A. M. and León, M. (2011). The Spanish welfare state in European context. Surrey: Ashgate.

Lago, S. (2002). Nivelación interterritorial e ineficiencia de las decisiones presupuestarias: reflexiones para el caso español. Hacienda Pública Española, 162 (3), 79-97.

Martín, J. (2003). Nuevas fórmulas de gestión en las organizaciones sanitarias. Madrid: Fundación Alternativas.

McEwen, N. and Moreno, L. (2005). The territorial politics of welfare. Oxon: Routledge/ECPR.

Moreno, F. J. (2009). Del sistema sanitario de la Seguridad Social al Sistema Nacional de Salud descentralizado. En L. Moreno (ed.). Reformas de las politicas del bienestar en España. (pp. 101-136). Madrid: Siglo XxI. 
Oates, W. E. (1972). Fiscal Federalism. Nueva York: Harcourt Brace Jovanovich.

Palomo, L., Gené-Badia, J. and Rodríguez-Sendín, J. (2012). La reforma de la atención primaria, entre el refugio del pasado y la aventura de la innovación. Gaceta Sanitaria, 26 (S), 14-19. Available at: https://doi.org/10.1016/j.gaceta.2011.06.010.

Rodríguez-Pose, A. and Gill, N. (2004). Is there a global link between regional disparities and devolution? Environment and Planning, A (36), 2097-2117. Available at: https://doi. org/10.1068/a362.

Ruiz-Huerta, J., Benyakhlef, V. and Vizán, C. (2010). Las comunidades autónomas ante la crisis económica: impacto territorial de la recesión, políticas autonómicas de reactivación y tensiones en las cuentas públicas. En M. Tornos. Informe comunidades autónomas 2009 (pp. 89-112). Barcelona: Instituto de Derecho Público.

Torrubia Romero, F. and Higuera González, J. (2011). Modelos de gestión sanitaria en Andalucía. En O. Marcenaro (ed.). Salud y bienestar social en Andalucía (pp. 13-34). Sevilla: Fundación Pública Andaluza, Centro de Estudios Andaluces.

Urbanos, R. (2006). El gasto sanitario y su financiación: evolución, tendencias y reflexiones para el futuro, Revista Asturiana de Economía, 35, 45-65.

Vilalta, M. (2005). La reforma del sistema de financiación de las comunidades autónomas. En VV. AA. Estado autonómico: integración, solidaridad, diversidad (pp. 635-652). Madrid: Instituto Nacional de Administración Pública.

- (2007). Los problemas actuales de la financiación autonómica. En S. Lago (dir.). La financiación del Estado de las autonomías: perspectivas de futuro (pp. 11-40). Madrid: Instituto de Estudios Fiscales. 


\section{ANNEX}

Figure 1. Evolution of the total resources from the funding model.

Liquidation 2002-2011

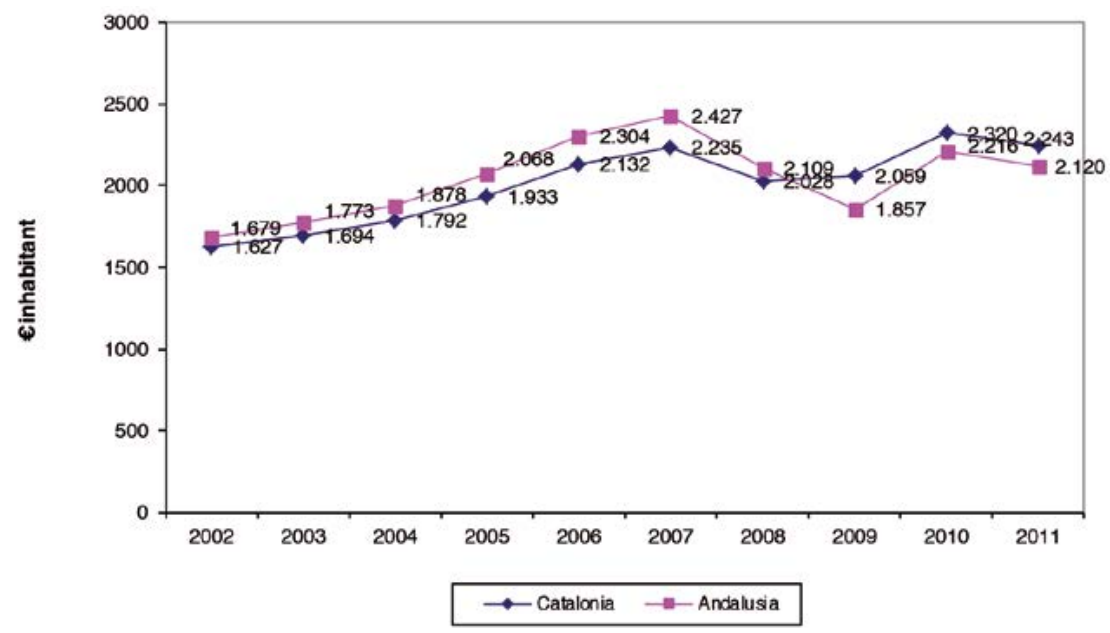

Source: The autors based on the Ministerio de Hacienda y Administraciones Públicas, INE.

Figure 2. Evolution of total revenue in Andalusia and Catalonia.

Liquidation 2002-2011

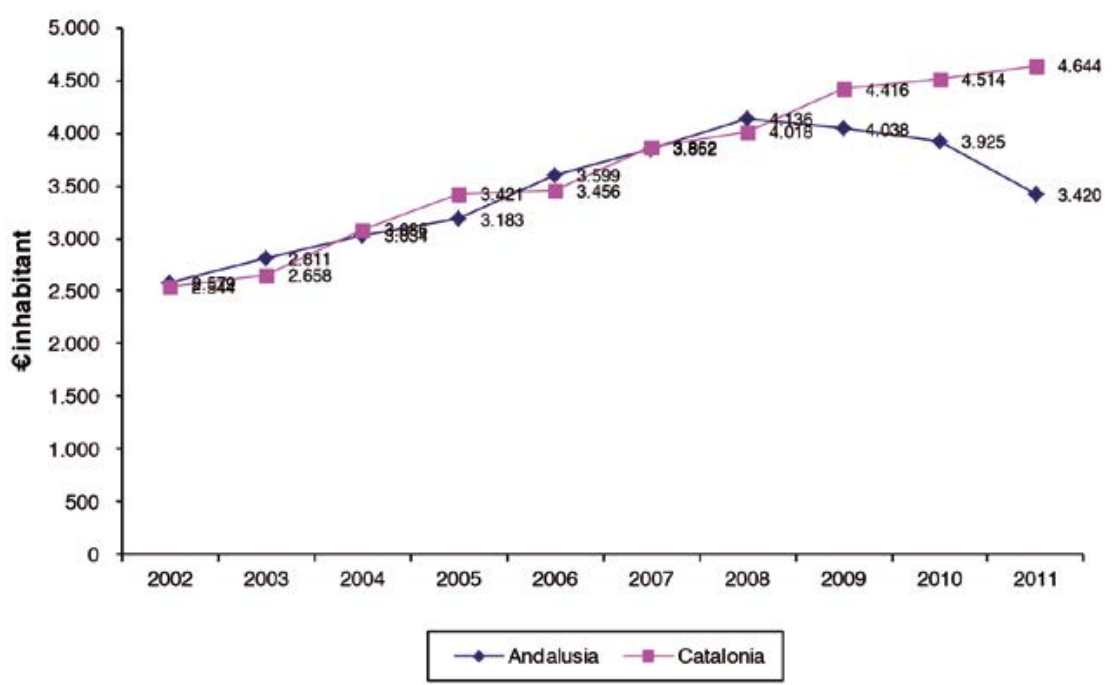

Source: The autors based on the Ministerio de Hacienda y Administraciones Públicas, INE. 
Figure 3. Health public expenditure. $€$ per inhabitant

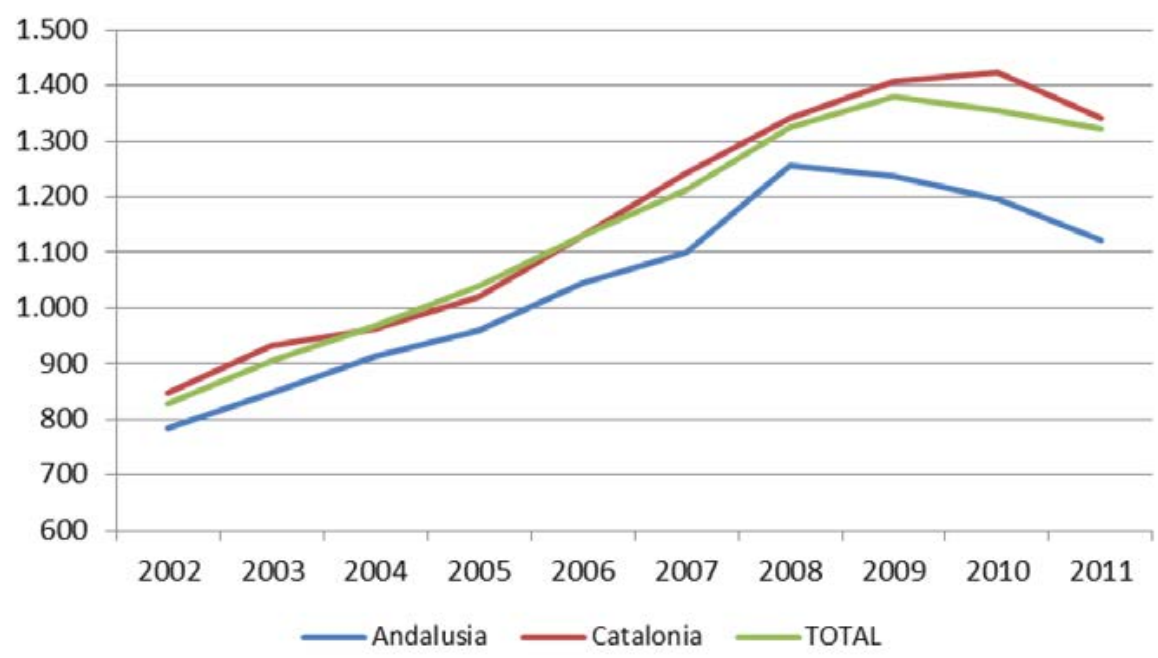

Source: The autors based on the Ministerio de Sanidad, Servicions Sociales e Igualdad, INE. 